\title{
The work-integrated learning combined with the portfolio method-A pedagogical strategy and tool in nursing education for developing professional competence
}

\author{
Sandra Pennbrant, Håkan Nunstedt \\ Department of Health Sciences, University West, Sweden
}

Received: July 30, 2017

DOI: $10.5430 /$ jnep.v8n2p8
Accepted: September 7, $2017 \quad$ Online Published: September 27, 2017

URL: https://doi.org/10.5430/jnep.v8n2p8

\begin{abstract}
During nursing education students obtain knowledge and skills to develop their professional competence. Teachers may elect to provide pedagogical tools preparing students for current and future healthcare needs. The purpose of this theoretical article was to highlight Work-Integrated Learning combined with the Portfolio Method as a pedagogical strategy and tool for nursing students to develop professional competence for lifelong learning. This strategy contains six phases: pre-reflection, reflection-in-action, reflection-on-action, self-evaluation, meta-reflection and knowledge-in-action, which can help nursing students, during their clinical education, develop deeper understanding of their future profession, while also providing a teaching planning tool.
\end{abstract}

Key Words: Pedagogical strategy, Portfolio method, Professional competence, Reflection, Work-integrated learning

\section{INTRODUCTION}

During their education nursing students obtain knowledge and skills needed to work as a nurse and develop their professional competence. It is expected of students in higher education to have an academic and scientific approach. Students must also be independent and have the ability to identify and solve problems. ${ }^{[1]}$ Knowledge is continuously being developed in society. Nurse education must take this development into account and give nursing students the opportunity to develop their professional competence, ${ }^{[2,3]}$ which is a prerequisite for high quality care. ${ }^{[4]}$ Nursing students' rights as regards the evaluation of their learning are not enshrined in legislation in most countries. However, there are widely endorsed codes of practice, legislative frameworks and standards intended to promote fairness and good practice. ${ }^{[5]}$ It is problematic for newly graduated registered nurses to meet the demands in terms of professional competence development that they face both from themselves and from their healthcare organizations. ${ }^{[6]}$ A challenge for teachers in nursing education is to provide students with pedagogical tools that can prepare them for both current demands as regards professional competence and future demands as regards lifelong learning. One way to promote the development of nursing students' professional competence is to use Work-Integrated Learning combined with the Portfolio Method (WIL-PM) as a pedagogical strategy and tool. The purpose of this theoretical article is to highlight WIL-PM as a pedagogical strategy and tool in nursing education for developing nursing students' professional competence in the perspective of lifelong learning.

*Correspondence: Sandra Pennbrant; Email: sandra.pennbrant@hv.se; Address: Department of Health Sciences, University West, Sweden. 


\section{AREA DESCRIPTIONS}

\subsection{Work-integrated learning}

The epistemological basis of Work-Integrated Learning (WIL) is sociocultural. In the sociocultural perspective people are in social and cultural interaction. The focus of the sociocultural perspective is cooperation and interaction as they are considered essential for learning. According to the sociocultural perspective, learning is achieved continuously through communication and interaction between the people involved, which in turn creates collective meaning. In the sociocultural perspective, learning means that all people learn all the time in any social context, with emphasis on the what of the learning. This means that the environment affects the development of the individual and the creation of their cognitive skills and knowledge. Vygotsky ${ }^{[7]}$ believes that learning precedes development. Learning and development are different processes that are interrelated and affect each other. As learning entails development, a range of development processes would be impossible without learning. Communication and language are central and constitute the link between the person and the environment, i.e. between the internal and the external interaction. ${ }^{[7,8]}$ The starting point of WIL is that humans are seen as social, creative and learning creatures with a focus on activities and relations that exist, occur and are deliberately created in and through their work. On the one hand, the focus is on the situational and contextual with questions about learning, change and knowledge- and competence development; on the other hand, it is on discursive or structural arrangements, power and resistance relationships based on class, gender and intersectionality in connection with changes in society and the workplace. ${ }^{[9]}$ Situated learning focuses on the context and the social interaction. ${ }^{[10]}$ Situated learning, practical learning and the sociocultural perspective are central issues in WIL and are linked through communication. ${ }^{[11]}$

WIL can be used at three levels: a) as an operational and educational profile focusing on the integration of theoretical and experiential knowledge, b) as an educational approach to higher education and learning in the workplace, and c) as a separate area of research. ${ }^{[9]}$ An exciting area of WIL research is institutional and inter-institutional learning issues in relation to a changing society and workplace. ${ }^{[9,12]}$ In this respect, WIL can be used to help organize vocational education and develop a common strategy between higher education and the workplace. In sum, WIL is about developing skills that can be used to improve the work performed and the work organization.

Professional development includes four steps. In the first step theory-based knowledge is transformed through reflec-

Published by Sciedu Press tion. In the second step learning is integrated into the work. In the third step experience-based knowledge is processed. In the fourth and last step learning is developed and can be integrated into the work as new skills. ${ }^{[13]}$ Consequently, WIL offers teachers and students an opportunity to achieve learning through reflective action, committed participation and testing of their knowledge. ${ }^{[14]}$

\subsection{Portfolio method}

The Portfolio Method's (PM) epistemological basis is constructivist. The focus in constructivism is that the person learns through experience and reflects on their different experiences. In this way, knowledge and understanding are created in interaction with the outside world. This means that we interpret what we know and can do on the basis of our experiences. There are two perspectives within constructivism: cognitive constructivism and social constructivism.

Cognitive constructivism believes that the person constructs their own knowledge and focuses on how people use information, resources, and help from others to build and improve their problem-solving strategies. ${ }^{[15-17]}$ Social constructivism sees learning as a process. Together with other people, the person improves their ability to participate in activities that are meaningful in the current culture. Social interactions are important when knowledge is constructed. People differ in their perceptions of reality and these perceptions are the result of social construction. This means that different people can perceive the same phenomenon in different ways. Dialogue is therefore important for developing mutual understanding. ${ }^{[18,19]}$ A person's understanding of reality is therefore a result of both context, culture, history and language. ${ }^{[19-21]}$

The perspectives, cognitive constructivism and social constructivism, are opposites. Cognitive constructivism focuses on "the inner thinking", whereas social constructivism focuses on "the external interaction". When a person is a part of the world, knowledge is created through the combination of these two perspectives. In order to develop both the internal and the external interaction with the environment, the PM uses both cognitive and social constructivism. This means that learners have the opportunity to take control of their learning, formulate their own targets, evaluate themselves and work independently to become more active in their learning. ${ }^{[8,22-24]}$

The PM is based on the theories of Dewey, Kolbs, Brookfields and Schön on reflection, on Bloom's taxonomy of learning outcomes, and on Perry's experimental model of "Intellectual development and learning in higher education". [25] The PM is used to monitor the development of knowledge, 
skills and attitudes in some area. The method is systematic with a structured collection of student work and is used by both teachers and students. ${ }^{[25]}$ With the help of the PM, it is possible to work across different disciplines. To understand the method the purpose of using it needs to be clear, one must know how to work with the method's material, and know how the method can be developed. ${ }^{[26,27]}$ The PM can be described as a flexible, evidence-based tool that engages students in a continuous reflection process along with others for the sake of learning. ${ }^{[25]}$ The PM can entail understanding of the future professional role and promote the development of critical thinking. ${ }^{[28]}$

The following concepts are used in the PM: self-regulation and self-efficacy beliefs, instructional scaffolding, narrativeexpressive storytelling, reflection and meta-cognition. Selfregulation is about having control over one's emotional life and thoughts and about changing and developing one's behavior in order to achieve desired goals. Self-regulation is based on the person's self-efficacy beliefs, i.e. their evaluation of their own ability to handle a specific task or situation. ${ }^{[24,29]}$ Instructional scaffolding is a metaphor used to facilitate the planning of teacher instruction, tutoring and teaching. Instructional scaffolding is used to provide the person with adequate support in their efforts to acquire or develop knowledge and skills. Examples of factors that can facilitate the learning experience can be objective descriptions, continuous feedback, gradually increasing complexity, and access to appropriate course material. Instructional scaffolding gives the person the opportunity to train their independent thinking and take responsibility for their own learning. ${ }^{[30]}$ Narrativeexpressive storytelling involves the person expressing their inner, emotional and intellectual notions about, for example, a situation, an event or a process. The purpose is to help the person develop tools to support both their own and the group's learning. ${ }^{[31]}$ Questions are needed to be able to use narrative-expressive storytelling to help the person reflect over their thoughts, emotions and experiences. ${ }^{[32,33]}$ Two groups of people do not seem to be able to use expressive writing constructively: those who use very few words to express (negative) emotions (a characteristic known as alexithymia), and those who make frequent and repetitive use of negatively-loaded words for emotions. For the purpose of writing about emotions, it is best to be located somewhere in between these extremes. According to Chung and Pennebaker, ${ }^{[33]}$ many people talk with others about what they have written, which leads to a continuous process. Reflection involves questioning and reassessment of the person's previous perceptions, evaluations, understanding and actions. Reflection means that students reflect about and exert control over their thinking. Emsheimer ${ }^{[34]}$ says that reflection differs qualitatively from everyday, mundane, spontaneous or superficial thinking; the reflection is more targeted, systematic and structured. The purpose of reflection is that the individual should distance themselves from former thought patterns by developing new ones. In this way, the person seeks answers to questions that can generate solutions and strategies in terms of good management. Meta-cognition is about the way a person solves tasks or finds solutions to problems. Meta cognitive skills offer the person the ability, after training, to consider their own way of perceiving and thinking from different perspectives, thus enabling the person to deliberately alter their habits of thought and approach in the learning process. ${ }^{[35]}$

\section{ONTOLOGICAL AND EPISTEMOLOGiCAL PERSPECTIVE ON WIL-PM}

WIL-PM is a pedagogical strategy and tool that focuses on situated learning as regards learning, development and socialization based on the social, historical, cultural, linguistic and historical context or contexts. ${ }^{[19-21]}$ Learning in the workplace is a form of situated learning where the student develops their professional identity. Situated learning means that we have a tendency to think and act in certain ways according to the routines and patterns of the current social context, ${ }^{[10]}$ and that skills and knowledge are bound to a specific situation. Situated learning is, therefore, difficult to apply in a new context. Social constructivism identifies five conditions for learning: 1) integrate learning in complex, realistic and relevant learning environments, 2) ensure that social discussions and shared responsibility become a part of the learning, 3) create opportunities for different perspectives and use multiple ways to represent the material, 4) cultivate self-awareness and understanding that knowledge is constructed, and 5) encourage students to be proactive in their own learning. ${ }^{[36,37]}$ According to Lave and Wenger, ${ }^{[38]}$ learning means to be invited and to participate in a culture that encompasses language, actions, tools, approaches and history. It is a question of growing into a culture. This approach involves identifying relevant information and interpreting it using already existing knowledge. Socialization is a process that involves learning and adapting to the culture and its standards in the current social context.

Learning is about creating knowledge and skills and WIL develops when an individual achieves knowledge that is both theory based and experiential. ${ }^{[13,39]}$ This means that knowledge also originates from action. Habermas ${ }^{[40]}$ distinguishes between three action interests: technical, practical and emancipatory. The technical action interest is about controlling the outside world, improving production and combating disease. 
The development of knowledge in this interest means being able to predict events. The practical action interest is about understanding each other and achieving knowledge through interpretation of the meaning of the communication between people. The purpose of the emancipation action interest is about making the person as free and independent as possible in terms of their autonomy and self-chosen activities. ${ }^{[1]}$

Pörn ${ }^{[42]}$ identifies various forms of knowledge for practical activities in areas such as health care: scientific knowledge, action knowledge, phronesis knowledge and understanding knowledge. Scientific knowledge is developed by people carrying out systematic studies on the basis of proven research methods and general theories of various kinds. Action knowledge is the knowledge a person has when they know what to do to achieve a given goal. Action knowledge contributes to the person's practical skills and can be gained through imitating others or learning through trial and error. Action knowledge is a form of practical knowledge. Phronesis knowledge is gained through reflection for the purpose of problem-solving and decision-making processes. Phronesis knowledge combined with self-control can be seen as wisdom. Understanding knowledge is about understanding the context, background and meaning of concepts, facts and words. There are similarities between Pörn's forms of knowledge and Aristotle's concepts of knowledge: episteme, techne and phronesis. Pörn's scientific knowledge corresponds to episteme, and Pörn's experience-based professional knowledge aspires to techne at advanced level. Phronesis is transposed into practice as moral reasoning in order to achieve the "good" in a given situation, often referred to as practical wisdom. Phronesis includes, in addition to being able to act wisely, understanding of why there is a specific way to achieve a goal in the specific context. Practical wisdom, or what Aristotle called praxis,${ }^{[42]}$ is therefore present in moral actions.

WIL-PM has a sociocultural perspective and cognitive and social constructivism as its theoretical starting point, meaning that the person constructs their own knowledge on the basis of and within the social, cultural, linguistic and historical context. Knowledge is therefore situated and evolves through collaboration where communication is a prerequisite for learning. WIL-PM takes into account the individual, social, cognitive and emotional dimensions during the learning process. Aristotle's concepts of knowledge with their fusion of theoretical and practical knowledge for the development of practical wisdom, Pörn's forms of knowledge for practical activities, and Habermas's emancipatory knowledge are all included in the WIL-PM view of knowledge.

Published by Sciedu Press

\section{RELEVANCE OF WIL-PM FOR NURSING STUDENTS IN CLINICAL PLACEMENT}

The nursing student's meeting with the healthcare system and the profession is an important experience for their development of a professional identity. The clinical placement gives the student the opportunity to meet and interact with supervisors and other professionals in clinical settings. ${ }^{[43]}$ The development of professional competence in a clinical context is a complex process and evolves gradually. Professional competence is based on theoretical knowledge, practical experience and personal maturity. Professional competence is developed in several steps ${ }^{[44]}$ and experience gained over a long time in similar clinical situations is required to achieve security and safety. ${ }^{[45]}$ In addition to practical and theoretical skills, it is necessary that the student and the professional nurse are socialized into a professional culture in order to cope with the profession and develop professional competence. ${ }^{[46]}$

The purpose of the clinical placement is to enable nursing students to add professional competence to their knowledge base by integrating theory with practice and vice-versa. There are many challenges for nursing students in the different learning situations experienced during their clinical placement. The students must deliberately and systematically think through their placement experiences. ${ }^{[47]}$ The students must ask questions and not take anything for granted. With the help of WIL-PM, used as a support in nursing students' learning processes, the students can document their reflections in a manageable and easy manner that can provide a basis for further processing. As a result, learning becomes part of the work through active knowledge exchange, reflected action and committed participation of the nursing students working in a clinical situation. Emancipatory knowledge, i.e. knowledge that enables the student to change, extend and develop their work, requires the intervention of someone who is not subject to the power that needs to be overcome ${ }^{[48]}$ Emancipation is achieved by learning the processes of reflection and self-reflection; new knowledge and understanding can free an individual from previously hampering conceptions. ${ }^{[37]}$ The processes of emancipation enable the person to become aware of their own potential by finding inherent knowledge, values, motivations and goals, and by linking these factors to actions. ${ }^{[40]}$

\subsection{WIL-PM for developing professional competence in nursing education and lifelong learning}

WIL-PM can be used as a pedagogical strategy and tool, both on campus and during clinical placement, to provide nursing students with opportunities to develop self-knowledge, highlighting their strengths and increasing their ability for 
self-learning and self-evaluation. It is therefore important that WIL-PM has a clear structure. The structure must ensure visibility, reinforce and develop what the nursing student is doing and how they have learned. It must also highlight the student's positive abilities and support their own responsibility for development and learning. In this way, the student can work in a self-regulated manner and achieve self-efficacy in order to manage different learning situations together with others in a social interaction. ${ }^{[24]}$

To enhance the efficacy of WIL-PM as a pedagogical strategy and tool, for both students and teachers, the method must be based on the theoretical learning objectives in the education and be integrated in the placement. Learning objectives can then be measured in order to develop knowledge. Learning starts in a concrete situation followed by reflection, concept formation and active experimentation. This process is consistent with Kolb' ${ }^{[49]}$ theory of experiential learning, which takes a holistic approach to learning encompassing cognition, behavior, experience and perception. According to Kolb, ${ }^{[49]}$ the experience is central in the learning process.

To facilitate the nursing students' cognitive processing of their perceptions and performances, WIL-PM must provide clear instructions, concrete reflection questions and the didactic questions, what, how, when, who and why. In order to sustain the learning process, it is crucial that the students document their reflections on a regular basis, both in action and after action, every day or several times a week.

WIL-PM can be used by the student as a tool for their active reflection and personal professional development. Dewey ${ }^{[50]}$ describes reflection as being creative and innovative, critical and questioning. According to Dewey, reflective thinking comprises five phases: 1) proposal, 2) intellectualization, 3) the guiding idea, 4) the hypothesis, and 5) reasoning. The phases do not always follow this order and the time spent on each of them may vary depending on the subject matter of the reflective thinking. The ability to structure knowledge consists largely of the person reviewing past facts and ideas. Subsequently, the person draws conclusions on the basis of these items. The reflection can then become exploratory and converted into new intellectual knowledge that, in turn, can become knowledge in action. The knowledge obtained in this way entails that a nursing student may change their actions in similar situations. The knowledge-based image developed by nursing students can also be used to better understand their knowledge of professional role development. ${ }^{[47]}$

During their education, nursing students should use WIL-PM to develop coping strategies to help them identify their own success factors. Coping strategies are reflection questions that focus on identifying the student's assets in terms of their achieved learning and professional development. WIL-PM can therefore be a powerful tool to strengthen the student's professional development during their nursing education. The result can be reflective nurses who continuously evaluate their knowledge and skills, and who can identify their own needs in the perspective of life-long learning.

\subsection{Methodological process of WIL-PM}

For WIL-PM to create conditions for nursing students to develop professional competence, the WIL must be systematized by using the portfolio structure and content. The following phases are included in the WIL-PM methodical process:

Phase 1: Pre-reflection. The nursing student identifies their understanding before an upcoming task or situation. The student asks the following questions: What is my knowledge of the area/topic? What is important to learn? How should it be learned? What activities are required? This creates a base-line for the current level of knowledge and skills to which one can relate in the continuing learning process.

Phase 2: Reflection-in-action. While doing their best to complete a task or situation the nursing student reflects about their work. Reflection-in-action means that the reflection is an integral part of the entire innovative process, involving the cognitive, emotional, intuitive and creative aspects involved in handling the task or situation. With the reflection-in-action WIL truly begins. The reflections that the student documents in phase two are based on the student's questions from phase one, pre-reflection. The student asks the following reflectionquestions: What is happening right now? How do I do this? Why do I feel like this? What knowledge do I need to deal with what is happening?

Phase 3: Reflection-on-action. The student summarizes the knowledge gained during the task or situation. With reflection-on-action the student can afterwards reflect on their actions and thoughts during the performance of the task or situation. On the basis of their pre-reflection, the student can combine the results of their reflection in and on action to form a comprehensive view of their level of knowledge. The student asks the following reflection-questions: What have I learned? What knowledge have I gained from documenting my pre-reflection? How have I learned? How can I support learning with the help of theory? How do I proceed with this knowledge? How can I translate this knowledge into action?

Phase 4: Self-evaluation. The overall picture of the knowledge that the student has developed in phase three, reflectionon-action, provides the basis for their self-evaluation. Selfevaluation means that the student processes their practical knowledge with their thoughts and emotions and relates the 
whole to the theoretical knowledge in order to understand the knowledge gained.

Phase 5: Meta-reflection. The student focuses on what they have learned and on the knowledge gained during the learning process. The meta-reflection uses the student's own evaluation and feedback from the previous reflection phases. The meta-reflection can also help the student identify their best individual learning style.

Phase 6: Knowledge-in-action. In this phase, the student becomes aware of how the new knowledge can best be put into action. The student asks the following reflection- questions: How can I use the theoretical and practical knowledge that I have identified during my clinical practice for everyday actions? How do I highlight my skills in everyday practical actions? What would I do differently with the support of the new knowledge?

All six phases provide the basis for developing professional competence. In this manner, WIL is used as a pedagogical strategy for lifelong learning and the Portfolio Method as the pedagogical tool used to facilitate this learning. Combined, WIL and the Portfolio Method can facilitate and promote the development of professional competence for students in nursing education (see Figure 1).

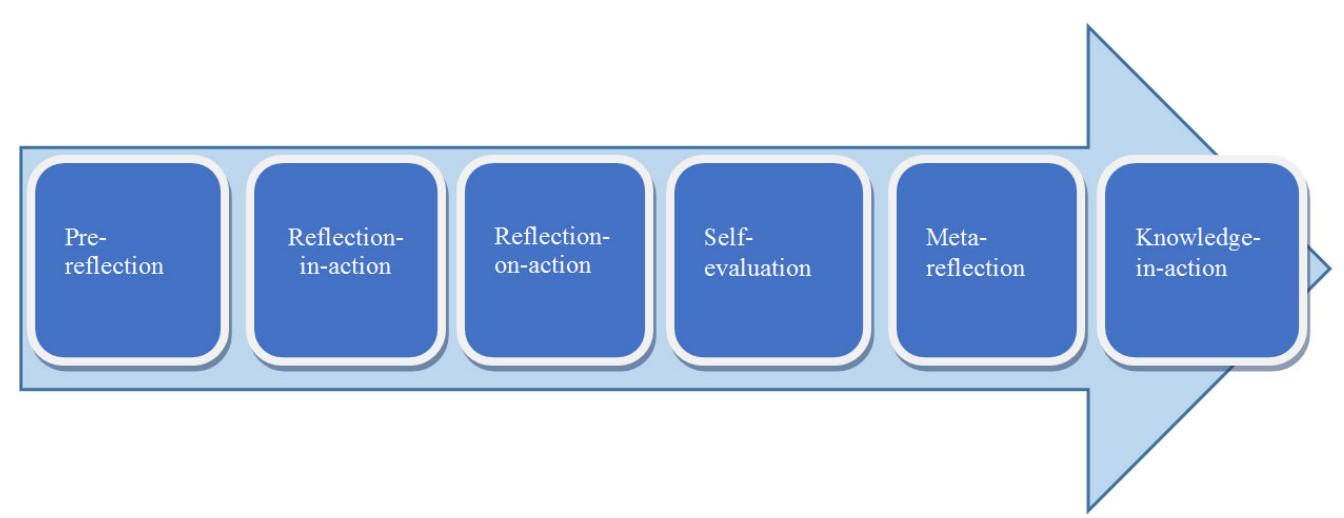

Figure 1. The work-integrated learning-portfolio method process

\section{Closing Reflections}

The overall purpose of nursing education is to combine theoretical and practical knowledge in order to develop the future nurses' ability to perform and reflect on their professional skills and experience. During their clinical placement, nursing students are supposed to gain deeper understanding of their future profession and role and to gain experience enhancing their abilities, knowledge and skills.

The WIL-PM approach is an active six-phase reflection process that supports the student's development of their learning and professional role. The WIL-PM approach encompasses the student's places of academic training and clinical placement and promotes the student's understanding of change and development in these areas. The focus is on learning, knowledge-exchange and knowledge development in order to enhance the nursing student's ability to continuously participate in changes in the workplace for lifelong learning.
The WIL-PM approach has a sociocultural perspective and cognitive and social constructivism as its theoretical starting point. The person is believed to construct their own knowledge on the basis of the cultural, linguistic, historical and social context. Knowledge is therefore situated and evolves through collaboration where communication is a prerequisite for learning. WIL-PM can serve as a strategy and tool for striking a balance between the theoretical, practical and ethical-moral knowledge areas, by taking into account the student's cognitive, emotional, individual and social dimensions during the learning process.

\section{ACKNOWLEDGEMENTS}

The authors thank Patrick Reis for editing and proofreading assistance.

\section{CONFlicts OF InTEREST Disclosure}

The authors declare that there is no conflict of interest.

\section{REFERENCES}

[1] National Board of Health and Welfare. 2005 Competence description for registered nurse. Available from: http://www.google.se/?gws_rd=ssl\#q=socialstyrel
sen+2005+kompetensbeskrivning+f\%C3\%B6r+legitimerad +sjuksk\%C3\%B6terska+stockholm [Accessed: 28th July 2017].

[2] Arthur H. Student self-evaluations: How useful? How valid? International Journal of Nursing Studies. 1995; 32: 271-276. https: 


\section{//doi.org/10.1016/0020-7489(94)00043-J}

[3] Klenowski V. An investigation of student self-evaluation as an authentic pedagogical practice: processes, possibilities and realities. University of London, Institute of Education; 1995.

[4] Andersson J. Vårdpersonal sökes. Vem behövs och vem vill arbeta i framtidens vård? [In search of healthcare professionals. Who is needed and who wants to work in future care?]. Stockholm: Swedish Association of Health Professionals; 2015.

[5] Gardner J, Holmes B. Students' Rights in Assessment and Evaluation. International Encyclopaedia of Education; 2010. https : //doi.org/10.1016/B978-0-08-044894-7.00353-5

[6] Jonsson B, Nilsson MS, Pennbrant S, et al. From work integrated learning to learning integrated work - A pedagogical model to develop praxis in nursing education. Journal of Nursing Education and Practice. 2014; 4(11): 91-100. https : //doi .org/10.5430/jnep .v4n11p91

[7] Vygotsky LS. Interaction between Learning and Development. In: Cole M, John-Steiner V, Scribner S, Souberman E (Eds). Mind in society: The development of higher psychological processes. Cambridge; mass: Harvard University Press; 1978.

[8] Säljö R. Lärande i praktiken. Ett sociokulturellt perspektiv [Learning in practice. A sociocultural perspective]. Stockholm: Bokförlaget Prisma; 2003. PMid:12965057

[9] Ekedahl L. Ansökan om tillstånd att utfärda examen på forskarnivå inom området arbetsintegrerat lärande (AIL) [Application for permission to award graduate-level degrees in the area of Work-Integrated Learning (WIL), University West]. Högskolan Väst, Dnr 2010/606 2010. Available from: http://www.hv.se/en [Accessed: 28th July 2017].

[10] Wenger E. Communities of Practice: Learning, Meaning and Identity. New York: Cambridge University Press; 1998. https ://doi.org/ 10.1017/CB09780511803932

[11] Mårdén B. Arbetsintegrerat lärande - bilder och motbilder [WorkIntegrated Learning - Images and counter-images]. Trollhättan, University West; 2007.

[12] Lagrosen S, Lund Snis U, Nehls E. Lärande i och för det nya arbetslivet - vad är det? [Learning in and for the new work life - what is it?] In: Lagrosen S, Lund Snis U, Nehls E (Eds). Lärande i och för det nya arbetslivet [Learning in and for the new working life]. Lund: Studentlitteratur; 2010

[13] Winroth J. Organisation som arena för hälsofrämjande arbete [Organization as an arena for health promotion work]. In: Eriksson M (Ed). Salutogenes - om hälsans ursprung. Från forskning till praktisk tillämpning [Salutogenes - On the origin of health. From research to practice]. Stockholm: Liber; 2015.

[14] Patrick CJ, Peach D, Pocknee C, et al. The WIL [Work Integrated Learning] report: A national scoping study [Australian Learning and Teaching Council (ALTC) Final report]. Brisbane, Australia: Queensland University of Technology; 2008.

[15] Piaget J. Understanding causality. New York: Norton; 1974. PMid:24414238

[16] Bruner JS. The narrative construction of reality. Critical Inquiry. 1991; 18(1): 1-21. https://doi.org/10.1086/448619

[17] von Glaserfeld E. Constructivism: A way of knowing and learning. London: Falmer Press; 1995. https ://doi.org/10.4324/9780 203454220

[18] Dysthe O. Om förhållandet mellan individ och grupp i portföljprocessen [On the relationship between individual and group in the portfolio process]. In: Dysthe O (Ed). Att bedöma eller döma. Tio artiklar om bedömning och betygssättning [To assess or judge. Ten articles on assessment and grading]. Stockholm: Skolverket Liber; 2002.
[19] Vygotsky LS. The Problem of Speech and Thinking in Piaget's Theory. In: Rieber RW, Carton AS (Eds). The Collected Works of L.S. Vygotsky. Problems of General Psychology, Including the Volume Thinking and Speech. New York: Plenum Press; 1987.

[20] Berger PL, Luckmann T. The Social Construction of Reality: A Treatise in the Sociology of Knowledge. Garden City, NY: Anchor Books; 1996.

[21] Burr V. Social Constructionism. London: Routledge; 2003.

[22] Ellmin R, Ellmin B. Portfolio - Teori, förhållningssätt och praktik [Portfolio - Theory, approach and practice]. Stockholm: Gothia; 2003.

[23] Zimmerman BJ. Self-regulatory cycles of learning. In: Straka GA (Ed). Conceptions of self-directed learning: Theoretical and conceptual considerations. New York: Waxman; 2000.

[24] Barry J, Zimmerman BJ, Schunk DH. Self-regulating intellectual processes and outcomes: A social cognitive perspective. In: Dai DY, Steinberg RJ (Eds). Motivation, emotion and cognition: Integrative perspectives on intellectual functioning and development. Mahwah, NJ: Lawrence Erlbaum; 2004.

[25] Murray JP. Successful faculty development and evaluation: The complete teaching portfolio. ASHE-ERIC Higher Education Report No. 8.Washington DC: George Washington University; 1995.

[26] McMullan M, Endacott R, Gray MA, et al. Portfolios and Assessment of Competence: A review of the literature. Journal of Advanced Nursing. 2003; 41(3): 283-294. PMid:12581116 https: //doi.org/10.1046/j.1365-2648.2003.02528.x

[27] Duque G, Finkelstein A, Roberts A, et al. Learning while evaluating: The use of an electronic evaluation portfolio in a geriatric medicine clerkship. BMC, Medical Education. 2006; 26(6): 4. https ://doi .org/10.1186/1472-6920-6-4

[28] Scholes J, Webb C, Gray M, et al. Making portfolios work in practice. Journal of Advanced Nursing. 2004; 46(6): 595-603. PMid:15154900 https://doi.org/10.1111/j.1365-2648.2004.03050.x

[29] Bandura A. Self-efficacy: The exercise of control. New York: Freeman; 1997.

[30] Bråten I. Vygotskij och pedagogiken [Vygotsky and pedagogics]. Lund: Studentlitteratur; 1998. PMid:9576841

[31] Kihlström S, Andersson E, Davidsson B, et al. Yrkesdagbok, reflektion, mentorskap: tre redskap i lärarutbildningen [Professional diary, reflection, mentorship: three tools in teacher education]. Borås: Institutionen för pedagogik, Högskolan i Borås; 2006.

[32] Ramirez-Esparza N, Pennebaker JW. Do good stories produce good health? Exploring words, language, and culture. Narrative Inquiry. 2006; 16(1): 211-219. https://doi.org/10.1075/ni.16.1.26 ram

[33] Chung CK, Pennebaker JW. The psychological function of function words. In: Fiedler K (Ed). Social communication: Frontiers of social psychology. New York: Psychology Press; 2007.

[34] Emsheimer P. Metod och reflektion [Method and reflection]. In: Emsheimer $\mathrm{P}$, Hansson $\mathrm{H}$, Koppfeldt $\mathrm{T}$ (Eds). Den svårfångade reflektionen [The elusive reflection]. Lund: Studentlitteratur; 2005

[35] Veenman M, Van Hout-Wolters B, Afflerbach P. Metacognition and learning: Conceptual and methodological considerations. Metacognition and Learning. 2006; 1: 3-14. https : //doi .org/10.1007/s1 1409-006-6893-0

[36] Moscovici S. The phenomenon of social representations. In: Farr RM, Moscovici S (Eds) Social representations. Paris: Cambridge University Press; 1984.

[37] Gergen KE. An invitation to social construction. London: Sage; 1999.

[38] Lave J, Wenger E. Situated learning. Legitimate peripheral participation. Cambridge: Cambridge University Press; 1991. https: //doi.org/10.1017/CB09780511815355 
[39] Thång PO. Om arbetsintegrerat lärande [About Work-Integrated Learning]. In: Theliander J, Grundén K, Mårdén B, Thång PO (Eds). Arbetsintegrerat lärande [Work-integrated learning]. Lund: Studentlitteratur; 2004.

[40] Habermas J. Knowledge and Human Interests. Boston: MA: Beacon Press; 1972.

[41] Pörn I. Filosofi - visdom för vår tid. In: Venkula J (Ed). Ajatuksen Voima. Jyväskylä, Finland; 1990.

[42] Balaban O. Praxis and poesies in Aristotle's practical philosophy. Journal of Value Inquiry. 1990; 24: 185-198. https ://doi .org/ 10.1007/BF00149432

[43] Sonesson A, Strand P, Gummesson C, et al. Forskningsbaserad utveckling av undervisning och lärande inom medicinska professionsutbildningar [Research-based development of teaching and learning in medical professional education]. In: Persson A, Johansson R (Eds). Vetenskapliga perspektiv på lärande, undervisning och utbildning $\mathrm{i}$ olika institutionella sammanhang: utbildningsvetenskaplig forskning vid Lunds universitet [Scientific perspectives on learning, teaching and education in various institutional contexts: Educational science at Lund University]. Institutionen för utbildningsvetenskap. Lund: Lunds University; 2014.

[44] Benner P. From novice to expert: Excellence and power in clinical nursing practice. Menlo Park, Calif.,: Addison-Wesley; 1984.

[45] Dreufys H, Dreufys S. Mind over machine. The power of human intuition and expertise in the era of the computer. New York: Free Press; 1986.

[46] MacIntosh J. Reworking professional nursing identity. Western Journal of Nursing Research. 2003; 25(69): 725-741. PMid:14528619 https://doi .org/10.1177/0193945903252419

[47] Schön D. Educating the reflective practioners: Toward a new design for teaching and learning in the professions. San Francisco: Jossey-Bass; 1987.

[48] Bingham C, Biesta G. Jacques Rancière: Education, truth, emancipation. New York: Continuum; 2010.

[49] Kolb D. Experiental learning as the science of learning and development. Englewood Cliffs, NY: Prentice Hall; 1984.

[50] Dewey J. How we think: A restatement of the relation of reflective thinking to the educative process. In: The later works of John Dewey. Carbondale: Southern Illinois University Press; 1933: 105-352. 